Original Research Paper

\title{
Effect of Lipid Levels on the Growth Performance and Hepatic Lipid Deposition in the Post-Larval Coho Salmon (Oncorhynchus kisutch)
}

\author{
1,2*Hairui Yu, ${ }^{1}$ Jinqing Wang and ${ }^{2 *}$ Dongwu Liu \\ ${ }^{1}$ Key Laboratory of Biochemistry and Molecular Biology in Universities of Shandong (Weifang University), \\ Weifang Key Laboratory of Coho Salmon Culturing Facility Engineering, \\ Institute of Modern Facility Fisheries, Weifang University, Weifang 261061, China \\ ${ }^{2}$ School of Agricultural Engineering and Food Science, Shandong University of Technology, Zibo 255049, China
}

\author{
Article history \\ Received: 26-03-2021 \\ Revised: 28-04-2021 \\ Accepted: 03-05-2021 \\ Corresponding Author: \\ Hairui $\mathrm{Yu}$ \\ Key Laboratory of \\ Biochemistry and Molecular \\ Biology in Universities of \\ Shandong (Weifang \\ University), Weifang Key \\ Laboratory of Coho Salmon \\ Culturing Facility Engineering, \\ Institute of Modern Facility \\ Fisheries, Weifang University, \\ Weifang 261061, China \\ Email: yhr6003@hotmail.com

\section{Dongwu Liu} \\ School of Agricultural \\ Engineering and Food Science, \\ Shandong University of \\ Technology, Zibo 255049, \\ China \\ Email: liudongwu888@126.com
}

\begin{abstract}
In this study, the effect of different lipid levels (6.6, 10.56, $15.43,18.91,22.52$ and $26.91 \%$ ) on the body composition, growth performance and lipid deposition was investigated in the post-larval coho salmon (Oncorhynchus kisutch). The results showed that the optimum lipid level for post-larval coho salmon was $15.8 \%$ based on the Specific Growth Ratio (SGR). Moreover, 15.43, 18.91, 22.52 and 26.91\% lipid levels significantly elevated the content of crude lipid in fish. However, the moisture, ash and crude protein was not significantly influenced by various lipid levels. The lipid levels of 18.91, 22.52 and $26.91 \%$ significantly elevated the content of TC, TG and NEFA, whereas significantly decreased the activity of FAS, ACC and ACL in the liver of coho salmon. In addition, the higher lipid levels significantly increased the activity of HL and LPL in liver. The total content of Saturated Fatty Acids (SFA) was increased but that of Polyunsaturated Fatty Acids (PUFA) was decreased by 18.91, 22.52 and 26.91\% lipid levels. In all, the appropriate lipid levels had positive effects on the growth performance and hepatic lipid deposition of the post-larval coho salmon. Our results will be beneficial for optimizing the use of lipid in the diets of Coho salmon.
\end{abstract}

Keywords: Lipid Levels, Fatty Acid Composition, Growth, Lipid Deposition, Coho Salmon

\section{Introduction}

As one of main components of fish diets, lipid is a key energy substance for the growth of fish species. Moreover, lipid not only provides the essential fatty acids, phospholipids and steroids, but also promotes the absorption and transportation of fat-soluble vitamins (Panserat et al., 2019; Paulino et al., 2020). Previously, the effects of lipid levels on fish growth have been studied in Rachycentron canadum, Oncorhynchus mykiss and Sillago sihama (Liu et al., 2021; Song et al., 2018; Wang et al., 2005). It is found that the appropriate lipid levels in diets are beneficial for fish growth. However, the insufficient supply of dietary lipids will lead to the deficiency of the essential fatty acids and affect fish growth.
Recently, with the increasing usage of high-fat diets in the fish aquaculture, the negative effects of excessive dietary lipids has been observed in some fish species (Gou et al., 2019; Hua et al., 2019; López et al., 2006). The high dietary lipid levels not only affect the absorption and utilization of nutrients, but also lead to the abnormal hepatic or visceral lipid deposition in fish species (Cai et al., 2017; Paulino et al., 2020). In addition, the abnormal lipid deposition further affects the lipid metabolism and immunity of fish (Mir et al., 2020). Thus, the studies on dietary lipid levels will make a better use of lipid in fish aquaculture. Moreover, the digestive ability is different for the different growth stages of fish species. The significant differences on the nutrients demand have been observed in the different growth stages of fish species 
(Alam et al., 2020; Busti et al., 2020; Canosa and Bertucci, 2020; Lopes et al., 2021; Pereira et al., 2019).

In addition, it is known that fat has the protein saving effect in animals (Silva-Brito et al., 2019; Tian et al., 2015; Xie et al., 2021). The protein sparing effect by fat has been observed in various studies and the protein utilization could be promoted by adding suitable lipid levels in fish diets (Jiang et al., 2015; Wang et al., 2005; 2019). Furthermore, the protein sparing effect could decrease the discharge of nitrogen-containing waste into the water environment (Watanabe, 2002). Recently, the study on optimizing dietary lipid levels has been given more attention (Nayak et al., 2018). Therefore, in the current study, the effect of lipid levels on the growth performance, body composition, fat acid composition and hepatic lipid deposition was to be investigated in the postlarval coho salmon (Oncorhynchus kisutch).

\section{Materials and Methods}

\section{Experimental Diets}

Six diets were formulated by adding 6 levels of lipid into diets (Table 1). The diets were made by using a double-screw extruder and dried in a ventilated oven for $12 \mathrm{~h}$ at $40^{\circ} \mathrm{C}$. The final concentration of lipid in diets was 6.6, 10.56, 15.43, 18.91, 22.52 and 26.91\% after detected with Folch method (Folch et al., 1957). Then the following experiments were performed as the process map (Fig. 1).

\section{Animals and Procedures}

The coho salmon $(0.39 \pm 0.03 \mathrm{~g})$ were put into 18 tanks (100 fish in each tank) with continuous aeration and freshwater in a re-circulating aquaculture system (Linyi, China). After 2-weeks' acclimatization, each lipid level diet was assigned to three tanks, respectively. Then fish were fed to satiation four times daily (7:00, 10:30, 14:00 and $17: 30$ ) at about $5 \%$ of whole body weight for 12 weeks. All animal procedures were approved by Weifang University of China's Institutional Animal Care Committee.

\section{Sample Collection}

12 weeks later, the total number of fish in each tank were counted and fish were deprived of feed for $24 \mathrm{~h}$ before sampling. Then fish were anaesthetized with 0.1 $\mathrm{g} / \mathrm{L}$ MS 222 and weighed to determine the growth performance. 12 fish were randomly sampled from each tank for analyzing crude protein, crude lipid, Dry Matter (DM) and ash in whole fish body, respectively. Moreover, the livers were sampled from 10 fish in each tank for detecting the activities of enzymes related to lipid metabolism.

\section{Proximate Composition Analysis}

Crude protein levels in the diets and whole body were detected from the determination of total nitrogen by Kjeldahl digestion (Kjeltec 8400, Foss Tecator, Sweden).
The crude lipid content in samples was detected with Folch method (Folch et al., 1957). The water content was assayed by drying at $105^{\circ} \mathrm{C}$ and the ash content was estimated through combustion using a muffle furnace at $550^{\circ} \mathrm{C}$ for $4 \mathrm{~h}$.

\section{Growth Performance and Feed Utilization Analysis}

The calculation formulae for the growth performance and feed utilization are as follows:

- $\operatorname{Survival}(\%)=100 \times($ final amount of fish $) /($ initial amount of fish)

- $\quad$ Specific Growth Ratio $(\mathrm{SGR})=100 \times[\ln ($ final body weight) - - In (initial body weight)]/days

- Hepatosomatic Index $($ HSI $)=[100 \times$ (liver weight/body weight)]

- Viscerosomatic Index $(\mathrm{VSI})=[100 \times($ viscera weight/body weight)]

- Condition Factor $(\mathrm{CF})=\left(\right.$ body weight/body length $\left.{ }^{3}\right)$ $\times 100$

- $\quad$ Feed Conversion Rate $(\mathrm{FCR})=$ feed intake/(final body weight-initial body weight)

\section{Assay the Activities of Lipid Metabolism Enzymes}

Liver samples were homogenized in $0.1 \mathrm{M} \mathrm{pH} 7.4$ Tris- $\mathrm{HCl}$ buffer at $4{ }^{\circ} \mathrm{C}$ and the supernatants were collected for enzyme analysis. The activities of Hepaticlipase (HL) and Lipoprteinlipase (LPL) as well as the levels of Nonesterified Fatty Acids (NEFA), Total Cholesterol (TC) and Triglyceride (TG) were assayed with the commercial kits (Nanjing Jiancheng Bioengineering Institute, China). The activities of Acetyl-CoA Carboxylase (ACC), ATP-Citrate lyaSE (ACL) and Fatty Acid Synthetase (FAS) were assayed with the commercial kits purchased from Zhuocai biology Co., Ltd. (Shanghai, China).

\section{Fatty Acid Analysis}

The liver samples were freeze-dried for $48 \mathrm{~h}$ and the fatty acid contents were detected with a GC-MS chromatograph (Agilent Technologies 7890-5977A, USA) according to a previous method (Xu et al., 2010).

\section{Statistical Analysis}

Data were presented as mean values \pm standard error of mean (s.e.m). SPSS 16.0 (SPSS Inc., 2005, USA) was used to perform the statistical analyses. Regression analysis was used for analyzing the optimum lipid level. In addition, the normality and homogeneity of variances among groups were tested and results were subjected to one-way Analysis of Variance (ANOVA) followed by Tukey's test. Differences were considered significant at $P<0.05$. 


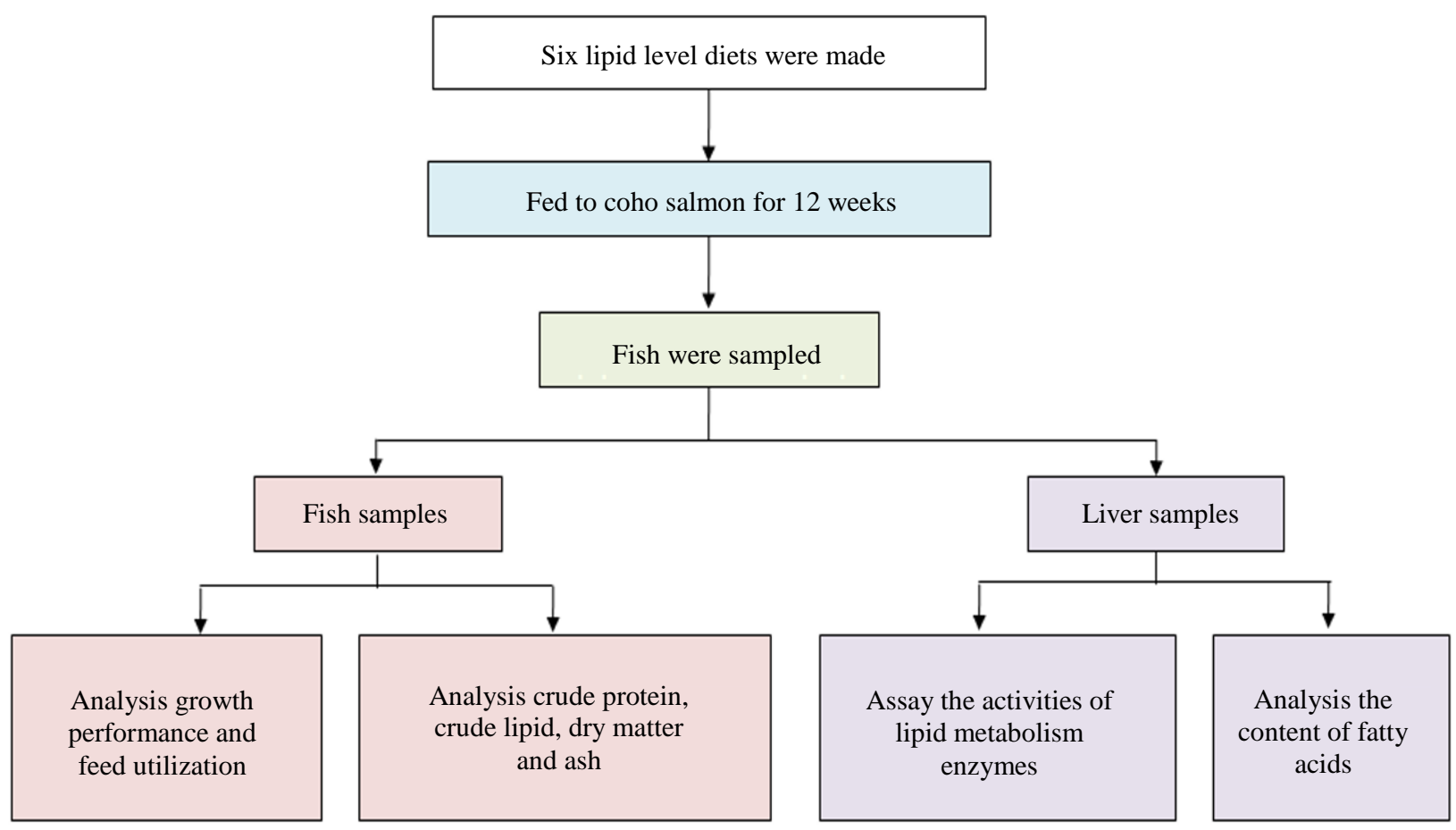

Fig. 1: The process map of the experiment. Six lipid level diets were made and fed to Coho salmon for 12 weeks. Then fish were sampled for various analysis

Table 1: Formulation and proximate composition of the experimental diets ( $\%$ in dry matter)

\begin{tabular}{|c|c|c|c|c|c|c|}
\hline \multirow[b]{2}{*}{ Ingredients } & \multicolumn{6}{|c|}{ Dietary lipid levels (\%) } \\
\hline & 6.6 & 10.56 & 15.43 & 18.91 & 22.52 & 26.91 \\
\hline Fish meal $^{1}$ & 40.00 & 40.00 & 40.00 & 40.00 & 40.00 & 40.00 \\
\hline Hydrolyzed fish meat protein ${ }^{1}$ & 5.00 & 5.00 & 5.00 & 5.00 & 5.00 & 5.00 \\
\hline Soybean meal ${ }^{1}$ & 20.00 & 20.00 & 20.00 & 20.00 & 20.00 & 20.00 \\
\hline Peanut meal ${ }^{1}$ & 9.80 & 9.80 & 9.80 & 9.80 & 9.80 & 9.80 \\
\hline$\alpha-\operatorname{Starch}^{1}$ & 20.00 & 16.00 & 12.00 & 8.00 & 4.00 & 0.00 \\
\hline Sodium alginate $^{1}$ & 2.00 & 2.00 & 2.00 & 2.00 & 2.00 & 2.00 \\
\hline Soybean lecithin ${ }^{1}$ & 1.80 & 1.80 & 1.80 & 1.80 & 1.80 & 1.80 \\
\hline Fish oil $^{1}$ & 0.00 & 2.00 & 4.00 & 6.00 & 8.00 & 10.00 \\
\hline Soybean oil ${ }^{1}$ & 0.00 & 2.00 & 4.00 & 6.00 & 8.00 & 10.00 \\
\hline Mineral premix ${ }^{2}$ & 0.50 & 0.50 & 0.50 & 0.50 & 0.50 & 0.50 \\
\hline Vitamin premix ${ }^{3}$ & 0.50 & 0.50 & 0.50 & 0.50 & 0.50 & 0.50 \\
\hline Ascorbic acid phosphate & 0.10 & 0.10 & 0.10 & 0.10 & 0.10 & 0.10 \\
\hline Choline chloride & 0.25 & 0.25 & 0.25 & 0.25 & 0.25 & 0.25 \\
\hline Ethoxyquin & 0.05 & 0.05 & 0.05 & 0.05 & 0.05 & 0.05 \\
\hline \multicolumn{7}{|l|}{ Proximate composition } \\
\hline Moisture (\%) & 7.31 & 7.26 & 7.27 & 7.11 & 7.18 & 7.20 \\
\hline Crude protein $(\%)$ & 45.73 & 45.90 & 45.90 & 45.73 & 46.00 & 46.01 \\
\hline Crude lipid (\%) & 6.60 & 10.56 & 15.43 & 18.91 & 22.52 & 26.91 \\
\hline $\operatorname{Ash}(\%)$ & 11.06 & 10.96 & 10.83 & 10.82 & 10.52 & 10.79 \\
\hline
\end{tabular}

${ }^{1}$ Provided by Shandong Conqueren Marine Technology Co., Ltd., Weifang, China

${ }^{2}$ Composition (mg kg-1 mineral premix): $\mathrm{AlK}\left(\mathrm{SO}_{4}\right)_{2} \cdot 12 \mathrm{H}_{2} \mathrm{O}, 123.7 ; \mathrm{CaCl}_{2}, 17879.8 ; \mathrm{CuSO}_{4} \cdot 5 \mathrm{H}_{2} \mathrm{O}, 31.7 ; \mathrm{CoCl}_{2} \cdot 6 \mathrm{H}_{2} \mathrm{O}, 48.9$; $\mathrm{FeSO}_{4} \cdot 7 \mathrm{H}_{2} \mathrm{O}, 707.4 ; \mathrm{MgSO}_{4} \cdot 7 \mathrm{H}_{2} \mathrm{O}, 4316.8 ; \mathrm{MnSO}_{4} \cdot 4 \mathrm{H}_{2} \mathrm{O}, 31.1 ; \mathrm{ZnSO}_{4} \cdot 7 \mathrm{H}_{2} \mathrm{O}, 176.7, \mathrm{KCl}, 1191.9 ; \mathrm{KI}, 5.3 ; \mathrm{NaCl}, 4934.5$; $\mathrm{Na}_{2} \mathrm{SeO}_{3} \cdot \mathrm{H}_{2} \mathrm{O}, 3.4 ; \mathrm{Ca}\left(\mathrm{H}_{2} \mathrm{PO}_{4}\right)_{2} \cdot \mathrm{H}_{2} \mathrm{O}, 12457.0 ; \mathrm{KH}_{2} \mathrm{PO}_{4}, 9930.2$

${ }^{3}$ Composition (IU or $\mathrm{g} \mathrm{kg}^{-1}$ vitamin premix): Retinal palmitate, 10,000 IU; cholecalciferol, 4,000 IU; $\alpha$-tocopherol, 75.0 IU; menadione, $22.0 \mathrm{~g}$; thiamine- $\mathrm{HCl}, 40.0 \mathrm{~g}$; riboflavin, $30.0 \mathrm{~g}$; D-calcium pantothenate, $150.0 \mathrm{~g}$; pyridoxine-HCl, 20.0 g; meso-inositol, $500.0 \mathrm{~g}$; Dbiotin, $1.0 \mathrm{~g}$; folic acid, $15.0 \mathrm{~g}$; ascorbic acid, $200.0 \mathrm{~g}$; niacin, $300.0 \mathrm{~g}$; cyanocobalamin, $0.3 \mathrm{~g}$ 


\section{Results}

Effect of Different Lipid Levels on the Growth Performance and Feed Utilization of Coho Salmon

Compared to the control, the lipid levels of 10.56, $15.43,18.91,22.52$ and $26.91 \%$ had no significant difference on the survival rate (Table 2). The final body weight was significantly increased by $10.65,15.43,18.91$ and $22.52 \%$ lipid levels (Table 2). In addition, the lipid levels of 15.43 and $18.91 \%$ significantly increased SGR, but the lipid level of $26.91 \%$ significantly increased FCR (Table 2). The results showed that the optimum lipid level was $15.8 \%$ based on SGR analysis (Fig. 2). However, no significant difference was observed on CF, HSI and VSI among various lipid levels treatments (Table 2).

\section{Effect of Different Lipid Levels on the Proximate Composition of Coho Salmon}

Compared to the control, 15.43, 18.91, 22.52 and $26.91 \%$ lipid levels significantly increased the content of crude lipid in the whole body of Coho salmon (Table 3). However, there was no significant difference between 6.60 and $10.56 \%$ lipid level treatments (Table 3). In addition, no significant difference was observed on moisture, ash and crude protein in the whole body among various lipid level treatments (Table 3 ).

Effect of Different Lipid Levels on the Activity of Lipid Metabolism Enzymes in the Liver of Coho Salmon

The treatments of 10.56, 15.43, 18.91, 22.52 and $26.91 \%$ lipid levels significantly enhanced the activity of HL in liver (Table 4). Moreover, the activity of LPL was significantly elevated by $15.43,18.91$ and $22.52 \%$ lipid levels (Table 4). The lipid levels of 18.91, 22.52 and 26.91\% significantly decreased the activity of FAS in liver (Fig. 3A). Furthermore, the activities of ACC and ACL were significantly decreased by the lipid levels of $18.91,22.52$ and $26.91 \%$ (Fig. 3B and 3C). No significant difference was found on the activity of FAS, ACC and ACL between the lipid levels of 6.60, 10.56 and $15.43 \%$ (Fig. 3A and 3C).

\section{Effect of Different Lipid Levels on the Lipid} Deposition Indexes in the Liver of Coho Salmon

Compared to the control, the lipid levels of 18.91, 22.52 and $26.91 \%$ significantly increased the content of TG and TC in liver (Fig. 4A and 4B). Moreover, the content of NEFA was significantly increased by the lipid levels of $18.91,22.52$ and $26.91 \%$ (Fig. 4C). No significant difference was found on the content of TG, TC and NEFA between 6.60, 10.56 and 15.43\% lipid level treatments (Fig. 4A and 4C).

Effect of Lipid Levels on the Fatty Acid Profiles in the Liver of Coho Salmon

The content of C16:0, C14:0 and C18:0 fatty acids was significantly increased, but that of C18:1n-9 and C22:1n9 was significantly decreased by the lipid levels of 18.91, 22.52 and $26.91 \%$ (Table 5). The content of C20:5n-3, C18:2n-6 and C22:6n-3 was significantly decreased by the lipid levels of 18.91, 22.5 and $26.91 \%$ (Table 5) and the content of C18:3n-3 was significantly decreased by the lipid levels of 22.52 and $26.91 \%$ (Table 5). Moreover, the total content of Saturated Fatty Acid (SFA) was significantly increased but that of Polyunsaturated Fatty Acid (PUFA) was significantly decreased by $18.91,22.52$ and $26.91 \%$ lipid level treatments (Table 5).

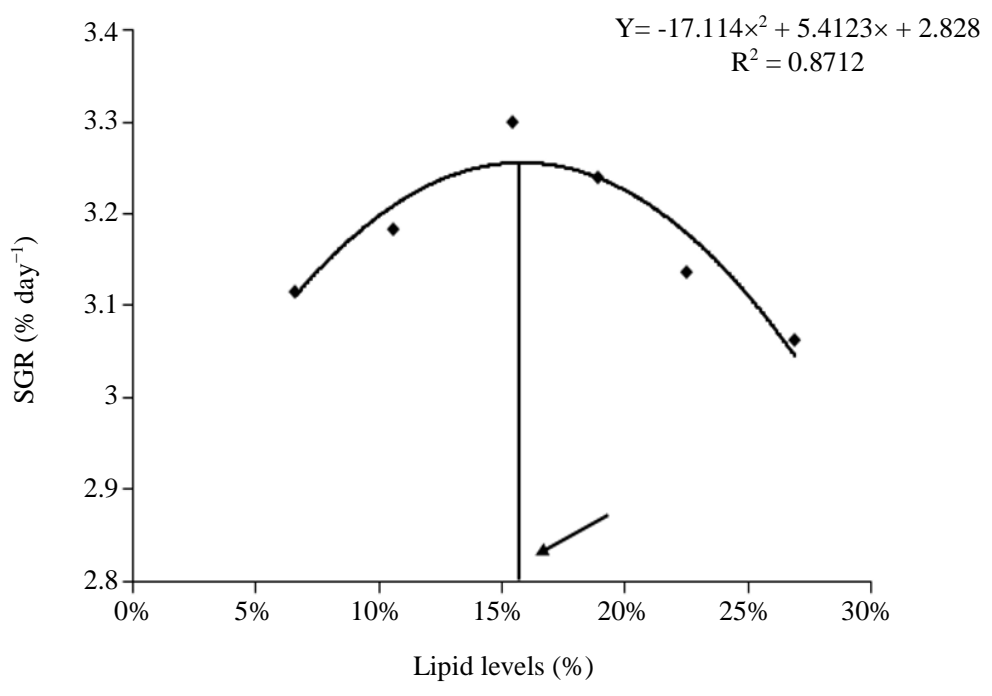

Fig. 2: The optimum dietary lipid level for post-larval Coho salmon. The optimum lipid level was $15.8 \%$ based on SGR for Coho salmon 


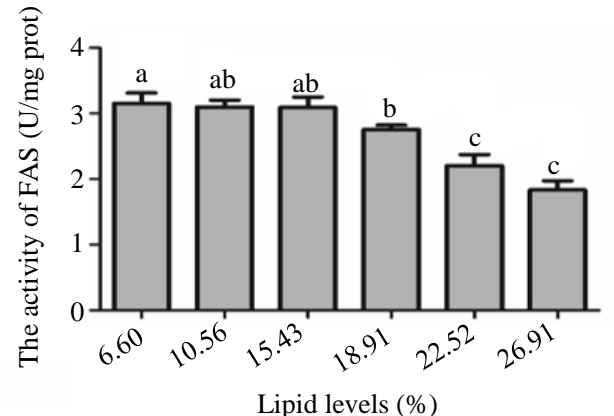

(a)

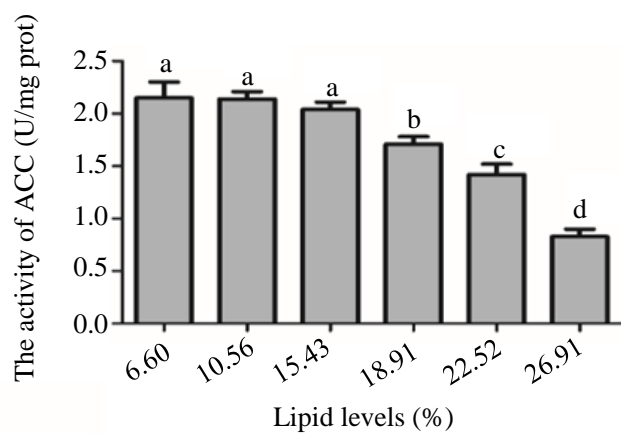

(b)

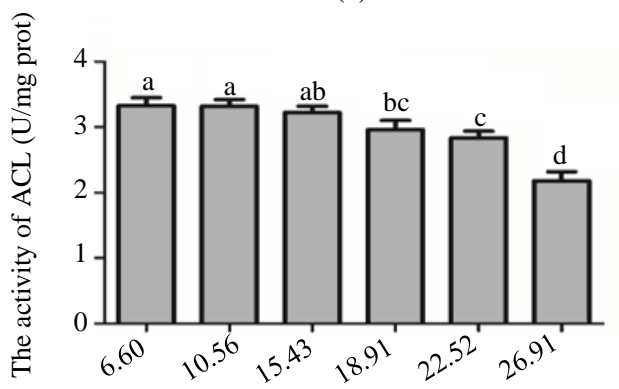

Lipid levels (\%)

(c)

Fig. 3: Effect of different lipid levels on the activity of FAS, ACC and ACL in liver. (A) Effect of different lipid levels on the activity of FAS. (B) Effect of different lipid levels on the activity of ACC. (C) Effect of different lipid levels on the activity of ACL

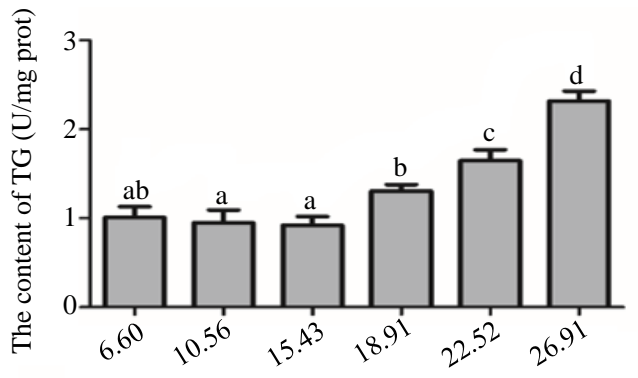

Lipid levels (\%)

(a)

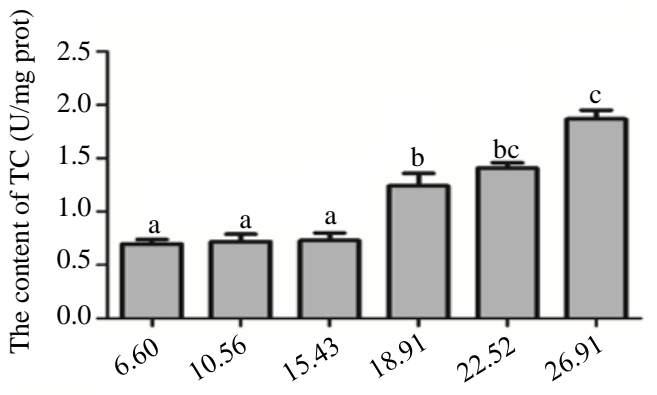

Lipid levels (\%)

(b)

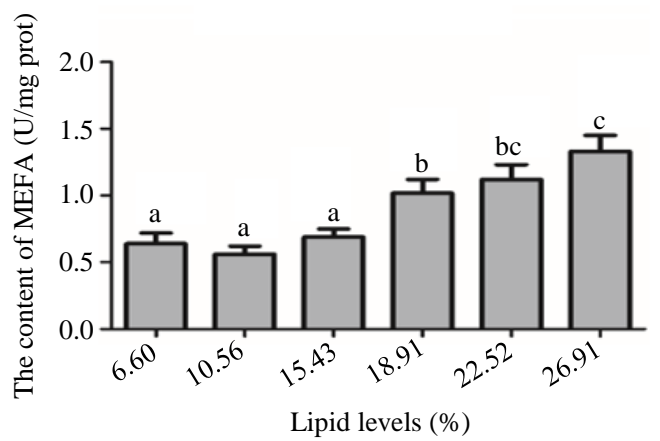

(c)

Fig. 4: Effect of different lipid levels on the content of TG, TC and NEFA in liver. (A) Effect of different lipid levels on the content of TG. (B) Effect of different lipid levels on the content of TC. (C) Effect of different lipid levels on the content of NEFA

Table 2: Effect of lipid levels on the growth performance and feed utilization

\begin{tabular}{lllllll}
\hline lipid levels & $6.60 \%$ & $10.56 \%$ & $15.43 \%$ & $18.91 \%$ & $22.52 \%$ & $26.91 \%$ \\
\hline Survival rate (\%) & $100.00 \pm 0.00^{\mathrm{a}}$ & $100.00 \pm 0.00^{\mathrm{a}}$ & $100.00 \pm 0.00^{\mathrm{a}}$ & $100.00 \pm 0.00^{\mathrm{a}}$ & $100.00 \pm 0.00^{\mathrm{a}}$ & $100.00 \pm 0.00^{\mathrm{a}}$ \\
Initial body weight $(\mathrm{g})$ & $0.38 \pm 0.02^{\mathrm{a}}$ & $0.39 \pm 0.01^{\mathrm{a}}$ & $0.38 \pm 0.02^{\mathrm{a}}$ & $0.38 \pm 0.03^{\mathrm{a}}$ & $0.39 \pm 0.01^{\mathrm{a}}$ & $0.39 \pm 0.02^{\mathrm{a}}$ \\
Final body weight $(\mathrm{g})$ & $5.24 \pm 0.07^{\mathrm{ab}}$ & $5.65 \pm 0.09^{\mathrm{c}}$ & $6.13 \pm 0.10^{\mathrm{d}}$ & $5.77 \pm 0.07^{\mathrm{c}}$ & $5.43 \pm 0.06^{\mathrm{b}}$ & $5.06 \pm 0.05^{\mathrm{a}}$ \\
SGR (\% day $)^{-1}$ & $3.11 \pm 0.04^{\mathrm{ab}}$ & $3.18 \pm 0.04^{\mathrm{abc}}$ & $3.30 \pm 0.06^{\mathrm{c}}$ & $3.24 \pm 0.09^{\mathrm{bc}}$ & $3.14 \pm 0.02^{\mathrm{ab}}$ & $3.06 \pm 0.07^{\mathrm{a}}$ \\
CF & $1.23 \pm 0.15^{\mathrm{a}}$ & $1.27 \pm 0.02^{\mathrm{a}}$ & $0.99 \pm 0.07^{\mathrm{a}}$ & $1.08 \pm 0.20^{\mathrm{a}}$ & $1.19 \pm 0.03^{\mathrm{a}}$ & $1.31 \pm 0.12^{\mathrm{a}}$ \\
FCR & $0.90 \pm 0.02^{\mathrm{ab}}$ & $0.89 \pm 0.02^{\mathrm{ab}}$ & $0.87 \pm 0.03^{\mathrm{a}}$ & $0.89 \pm 0.04^{\mathrm{a}}$ & $0.91 \pm 0.04^{\mathrm{ab}}$ & $0.98 \pm 0.03^{\mathrm{b}}$ \\
HSI & $1.15 \pm 0.02^{\mathrm{a}}$ & $1.28 \pm 0.20^{\mathrm{a}}$ & $1.26 \pm 0.06^{\mathrm{a}}$ & $1.13 \pm 0.06^{\mathrm{a}}$ & $1.04 \pm 0.01^{\mathrm{a}}$ & $1.26 \pm 0.15^{\mathrm{a}}$ \\
VSI & $1.03 \pm 0.04^{\mathrm{a}}$ & $1.04 \pm 0.18^{\mathrm{a}}$ & $1.43 \pm 0.18^{\mathrm{a}}$ & $1.22 \pm 0.07^{\mathrm{a}}$ & $1.45 \pm 0.21^{\mathrm{a}}$ & $1.30 \pm 0.05^{\mathrm{a}}$ \\
\hline
\end{tabular}

Values are expressed as means \pm s.e.m. $(n=3)$. Statistically significant differences are denoted by different letters $(P<0.05)$ 
Table 3: Effect of lipid levels on the whole-body composition of coho salmon

\begin{tabular}{lllllll}
\hline lipid levels & $6.60 \%$ & $10.56 \%$ & $15.43 \%$ & $18.91 \%$ & $22.52 \%$ & $26.91 \%$ \\
\hline Moisture (\%) & $76.98 \pm 0.69^{\mathrm{a}}$ & $77.45 \pm 0.02^{\mathrm{a}}$ & $76.91 \pm 0.26^{\mathrm{a}}$ & $77.85 \pm 0.14^{\mathrm{a}}$ & $77.98 \pm 0.58^{\mathrm{a}}$ & $78.27 \pm 0.67^{\mathrm{a}}$ \\
Crude protein (\%) & $12.26 \pm 0.49^{\mathrm{a}}$ & $12.42 \pm 0.26^{\mathrm{a}}$ & $12.37 \pm 0.04^{\mathrm{a}}$ & $13.58 \pm 0.83^{\mathrm{a}}$ & $13.02 \pm 0.19^{\mathrm{a}}$ & $12.68 \pm 0.01^{\mathrm{a}}$ \\
Crude lipid (\%) & $3.79 \pm 0.62^{\mathrm{a}}$ & $4.70 \pm 0.15^{\mathrm{ab}}$ & $5.63 \pm 0.36^{\mathrm{bc}}$ & $6.23 \pm 0.07^{\mathrm{c}}$ & $6.40 \pm 0.24^{\mathrm{c}}$ & $6.22 \pm 0.66^{\mathrm{c}}$ \\
Ash (\%) & $3.29 \pm 0.10^{\mathrm{a}}$ & $3.29 \pm 0.01^{\mathrm{a}}$ & $3.20 \pm 0.02^{\mathrm{a}}$ & $3.24 \pm 0.02^{\mathrm{a}}$ & $3.24 \pm 0.01^{\mathrm{a}}$ & $3.21 \pm 0.01^{\mathrm{a}}$ \\
\hline
\end{tabular}

Values are expressed as means \pm s.e.m. $(n=3)$. Statistically significant differences are denoted by different letters $(P<0.05)$

Table 4: Effect of lipid levels on the activity of HL and LPL in the liver of coho salmon

\begin{tabular}{lllllll}
\hline lipid levels & $6.60 \%$ & $10.56 \%$ & $15.43 \%$ & $18.91 \%$ & $22.52 \%$ & $26.91 \%$ \\
\hline HL (U/g prot.) & $0.52 \pm 0.03^{\mathrm{a}}$ & $0.65 \pm 0.01^{\mathrm{b}}$ & $0.68 \pm 0.03^{\mathrm{b}}$ & $0.69 \pm 0.01^{\mathrm{b}}$ & $0.76 \pm 0.01^{\mathrm{c}}$ & $0.70 \pm 0.01^{\mathrm{bc}}$ \\
LPL (U/g prot.) & $0.48 \pm 0.01^{\mathrm{a}}$ & $0.49 \pm 0.02^{\mathrm{a}}$ & $0.57 \pm 0.02^{\mathrm{bc}}$ & $0.58 \pm 0.01^{\mathrm{c}}$ & $0.58 \pm 0.03^{\mathrm{c}}$ & $0.52 \pm 0.01^{\mathrm{ab}}$ \\
\hline
\end{tabular}

Values are expressed as means \pm s.e.m. $(n=3)$. Statistically significant differences are denoted by different letters $(P<0.05)$

Table 5: Effect of lipid levels on the fatty acid composition in the liver ( $\%$ total fatty acids)

\begin{tabular}{|c|c|c|c|c|c|c|}
\hline \multirow[b]{2}{*}{ Fatty acid (\%) } & \multicolumn{6}{|l|}{ lipid levels } \\
\hline & $6.60 \%$ & $10.56 \%$ & $15.43 \%$ & $18.91 \%$ & $22.52 \%$ & $26.91 \%$ \\
\hline$\overline{\mathrm{C} 14: 0}$ & $1.61 \pm 0.07^{\mathrm{a}}$ & $1.64 \pm 0.03^{\mathrm{a}}$ & $1.66 \pm 0.05^{\mathrm{a}}$ & $2.21 \pm 0.11^{\mathrm{b}}$ & $3.32 \pm 0.10^{c}$ & $3.20 \pm 0.12^{\mathrm{c}}$ \\
\hline C16:0 & $22.25 \pm 0.22^{\mathrm{a}}$ & $22.35 \pm 0.12^{\mathrm{a}}$ & $22.18 \pm 0.20^{\mathrm{a}}$ & $23.83 \pm 0.41^{\mathrm{b}}$ & $24.76 \pm 0.21^{b}$ & $24.67 \pm 0.48^{b}$ \\
\hline C18:0 & $9.29 \pm 0.16^{\mathrm{a}}$ & $9.21 \pm 0.13^{\mathrm{a}}$ & $9.33 \pm 0.11^{\mathrm{a}}$ & $12.01 \pm 0.13^{\mathrm{b}}$ & $13.83 \pm 0.28^{c}$ & $13.63 \pm 0.38^{c}$ \\
\hline$\sum \mathrm{SFA}$ & $33.14 \pm 0.45^{\mathrm{a}}$ & $33.20 \pm 0.28^{\mathrm{a}}$ & $33.17 \pm 0.36^{\mathrm{a}}$ & $38.05 \pm 0.64^{\mathrm{b}}$ & $41.82 \pm 0.59^{c}$ & $41.50 \pm 0.97^{c}$ \\
\hline C16:1n-7 & $3.14 \pm 0.08^{\mathrm{a}}$ & $3.19 \pm 0.03^{\mathrm{a}}$ & $3.07 \pm 0.04^{\mathrm{a}}$ & $3.21 \pm 0.16^{\mathrm{a}}$ & $3.46 \pm 0.08^{\mathrm{a}}$ & $3.26 \pm 0.13^{\mathrm{a}}$ \\
\hline C18:1n-9 & $16.29 \pm 0.15^{\mathrm{a}}$ & $16.33 \pm 0.11^{\mathrm{a}}$ & $16.38 \pm 0.17^{\mathrm{a}}$ & $14.95 \pm 0.14^{\mathrm{b}}$ & $13.41 \pm 0.11^{\mathrm{c}}$ & $13.11 \pm 0.10^{c}$ \\
\hline C20:1n-9 & $2.29 \pm 0.08^{\mathrm{a}}$ & $2.22 \pm 0.03^{\mathrm{a}}$ & $2.27 \pm 0.05^{\mathrm{a}}$ & $2.39 \pm 0.06^{\mathrm{a}}$ & $2.48 \pm 0.12^{\mathrm{a}}$ & $2.43 \pm 0.10^{\mathrm{a}}$ \\
\hline C22:1n-9 & $3.25 \pm 0.15^{\mathrm{a}}$ & $3.36 \pm 0.12^{\mathrm{a}}$ & $3.21 \pm 0.09^{\mathrm{a}}$ & $2.21 \pm 0.17^{\mathrm{b}}$ & $2.23 \pm 0.11^{\mathrm{b}}$ & $2.19 \pm 0.13^{\mathrm{b}}$ \\
\hline$\sum$ MUFA & $24.97 \pm 0.45^{\mathrm{a}}$ & $25.10 \pm 0.29^{a}$ & $24.93 \pm 0.35^{\mathrm{a}}$ & $22.76 \pm 0.54^{b}$ & $21.58 \pm 0.34^{\mathrm{c}}$ & $20.99 \pm 0.46^{c}$ \\
\hline C18:2n-6 & $5.52 \pm 0.09^{a}$ & $5.42 \pm 0.11^{\mathrm{a}}$ & $5.56 \pm 0.08^{\mathrm{a}}$ & $5.25 \pm 0.05^{\mathrm{b}}$ & $5.23 \pm 0.09^{\mathrm{b}}$ & $5.18 \pm 0.14^{\mathrm{b}}$ \\
\hline C18:3n-3 & $1.94 \pm 0.07^{\mathrm{a}}$ & $1.91 \pm 0.04^{\mathrm{a}}$ & $1.84 \pm 0.08^{\mathrm{a}}$ & $1.21 \pm 0.07^{\mathrm{a}}$ & $1.57 \pm 0.06^{\mathrm{b}}$ & $1.46 \pm 0.12^{\mathrm{b}}$ \\
\hline$C 20: 5 n-3$ & $6.77 \pm 0.06^{\mathrm{a}}$ & $6.72 \pm 0.05^{\mathrm{a}}$ & $6.83 \pm 0.07^{\mathrm{a}}$ & $5.19 \pm 0.14^{\mathrm{b}}$ & $4.34 \pm 0.12^{\mathrm{c}}$ & $4.24 \pm 0.20^{c}$ \\
\hline$C 20: 4 n-6$ & $5.35 \pm 0.14^{\mathrm{a}}$ & $5.31 \pm 0.09^{a}$ & $5.45 \pm 0.16^{\mathrm{a}}$ & $5.36 \pm 0.06^{\mathrm{a}}$ & $5.51 \pm 0.19^{\mathrm{a}}$ & $5.39 \pm 0.14^{\mathrm{a}}$ \\
\hline$C 22: 6 n-3$ & $23.29 \pm 0.15^{\mathrm{a}}$ & $23.19 \pm 0.19^{a}$ & $23.25 \pm 0.11^{\mathrm{a}}$ & $22.43 \pm 0.39^{b}$ & $21.54 \pm 0.08^{c}$ & $21.40 \pm 0.19^{c}$ \\
\hline$\sum$ PUFA & $42.87 \pm 0.51^{\mathrm{a}}$ & $42.55 \pm 0.48^{\mathrm{a}}$ & $42.93 \pm 0.50^{\mathrm{a}}$ & $39.45 \pm 0.71^{\mathrm{b}}$ & $38.19 \pm 0.54^{\mathrm{c}}$ & $37.87 \pm 0.79^{c}$ \\
\hline
\end{tabular}

Values are expressed as means \pm s.e.m. $(n=3)$. Statistically significant differences are denoted by different letters $(P<0.05)$

\section{Discussion}

The essential fatty acids derived from lipids play a key role for the developmental, physiological and reproductive functions of fish species (Kandathil Radhakrishnan et al., 2020; Kumar et al., 2018; Pamungkas et al., 2020). Nevertheless, the excessive or insufficient dietary lipid levels may have negative effects on muscle quality, growth and disease resistance of fish species (Liu et al., 2021; Xu et al., 2020). Previously, it is observed that the appropriate content of lipid levels in diets improves the growth performance of Micropterus salmoides, Oncorhynchus mykiss and Scylla paramamosain (Guo et al., 2019; Meng et al., 2019; Xu et al., 2020). In this study, the final body weight was significantly increased by $10.65,15.43$, 18.91 and $22.52 \%$ lipid levels in the post-larval Coho salmon, which was consistent with these previous studies. Moreover, it has been found that the growth performance of large yellow croaker was not affected by moderate (12\% lipid level) and high (18\% lipid level) dietary lipid levels (Yan et al., 2015). For grass carp, the lipid level of $40 \mathrm{~g} / \mathrm{kg}$ has better effect on feed utilization and growth performance (Yuan et al., 2016). Our results showed that the optimum lipid level was $15.8 \%$ based on SGR and the appropriate lipid level had positive effect on the growth performance of Coho salmon. Thus, the different of lipid levels may be required for different fish species. In addition, our results will be beneficial for optimizing the use of lipid in the diets of Coho salmon.

In a previous study, the level of NEFA and TG was elevated in large yellow croaker fed with a higher lipid level diet (18\% lipid level) (Yan et al., 2015). However, $6 \%$ lipid level diet decreased the hepatic lipid content in the large yellow croaker (Yan et al., 2015). In our study, the lipid levels of 15.43, 18.91, 22.52 and 26.91 significantly increased the content of crude lipid. However, no significant difference was observed on moisture, ash and crude protein in six lipid level treatments. In addition, the higher lipid levels 18.91 , 22.52 and $26.91 \%$ significantly increased the level of TC, TG and NEFA in the liver of Coho salmon, which was consistent with the previous study. 
In the liver of grass carp, the biosynthesis of fatty acids was inhibited following the increase of lipid uptake (Yuan et al., 2016). In the present study, the lipid levels of $18.91,22.52$ and $26.91 \%$ decreased the activity of ACC, FAS and ACL in liver, but the lower lipid levels had no significant difference on these enzymes. In addition, the higher lipid levels enhanced the activity of HL and LPL in the liver of Coho salmon. It demonstrated that the different lipid levels affected the activities of FAS, ACC, ACL, HL and LPL, which may result in the difference on the hepatic lipid deposition.

In a previous study, the higher SGR and whole-body lipid content as well as the lower FCR were observed at a higher fish oil level $(120 \mathrm{~g} / \mathrm{kg} \mathrm{diet})$ in silver barb (Nayak et al., 2018). The level of SFA was increased, whereas MUFA level was decreased by higher fish oil levels in the muscle of silver barb (Nayak et al., 2018). In our study, the total content of SFA was increased but that of PUFA was decreased by $18.91,22.52$ and $26.91 \%$ lipid levels. It showed that the lipid levels affected the levels of SFA and PUFA. Previously, the content of n-3 LC-PUFA and n-3 PUFA was increased with the increase of fish oil levels in the liver and muscle of silver barb (Nayak et al., 2018). The difference maybe that the content of SFA and PUFA was related to the different fish species and growth stages of fish.

\section{Conclusion}

In summary, the effect of different lipid levels on the body composition, growth and lipid deposition was investigated in the post-larval Coho salmon. The results showed that the appropriate lipid levels had positive effect on growth performance. The higher levels of lipid treatments decreased the activity of enzymes related to lipid deposition, while increased the level of TC, TG and NEFA in liver. The total content of SFA was increased but PUFA was decreased by the higher levels of lipid treatments. In all, the appropriate lipid levels had positive effects on the growth performance and hepatic lipid deposition in the post-larval Coho salmon. The results will be beneficial for optimizing the use of lipid in the diets of Coho salmon.

\section{Acknowledgement}

This study was supported by Shandong Provincial Key Research and Development Programs (2019JZZY020710 and 2018CXGC0102), Scientific and Technologic Development Program of Weifang (2019ZJ1046) and Innovation-driven Development Special Project of Guangxi Science and Technology Major Project (AA17204044).

\section{Author's Contributions}

Hairui Yu and Jinqing Wang: Participated in all experiments and coordinated the data-analysis of the manuscript.
Dongwu Liu: Designed the research plan and organized the study.

\section{Ethics}

This article is original and contains unpublished material. The corresponding author confirms that all of the other authors have read and approved the manuscript and no ethical issues involved.

\section{References}

Alam, M. S., Liang, X. F., \& Liu, L. (2020). Indirect effect of different dietary protein to energy ratio of bait fish mori diets on growth performance, body composition, nitrogen metabolism and relative AMPK \& mTOR pathway gene expression of Chinese perch. Aquaculture Reports, 16, 100276. https://doi.org/https://doi.org/10.1016/j.aqrep.2020.1 00276

Busti, S., Bonaldo, A., Dondi, F., Cavallini, D., Yúfera, M., Gilannejad, N., ... \& Parma, L. (2020). Effects of different feeding frequencies on growth, feed utilisation, digestive enzyme activities and plasma biochemistry of gilthead sea bream (Sparus aurata) fed with different fishmeal and fish oil dietary levels. Aquaculture, 529, 735616. https://doi.org/https://doi.org/10.1016/j.aquaculture. 2020.735616

Cai, Z., Mai, K., \& Ai, Q. (2017). Regulation of hepatic lipid deposition by phospholipid in large yellow croaker. British Journal of Nutrition, 118(12), 999-1009. https://doi.org/10.1017/s000711451700294x

Canosa, L. F., \& Bertucci, J. I. (2020). Nutrient regulation of somatic growth in teleost fish. The interaction between somatic growth, feeding and metabolism. Molecular and Cellular Endocrinology, 111029. https://doi.org/https://doi.org/10.1016/j.mce.2020.11 1029

Folch, J., Lees, M., \& Stanley, G. S. (1957). A simple method for the isolation and purification of total lipides from animal tissues. Journal of Biological Chemistry, 226(1), 497-509. file://C:/Users/WindowS\%2010/Downloads/1957_ Folch_Lipids.pdf

Gou, N., Chang, Z., Deng, W., Ji, H., \& Zhou, J. (2019). Effects of dietary lipid levels on growth, fatty acid composition, antioxidant status and lipid metabolism in juvenile Onychostoma macrolepis. Aquaculture Research, 50(11), 3369-3381. https://doi.org/https://doi.org/10.1111/are.14295

Guo, J. L., Zhou, Y. L., Zhao, H., Chen, W. Y., Chen, Y. J., \& Lin, S. M. (2019). Effect of dietary lipid level on growth, lipid metabolism and oxidative status of largemouth bass, Micropterus salmoides. Aquaculture, 506, 394-400. https://doi.org/https://doi.org/10.1016/j.aquaculture. 2019.04.007 
Hua, K., Koppe, W., \& Fontanillas, R. (2019). Effects of dietary protein and lipid levels on growth, body composition and nutrient utilization of Channa striata. $\quad$ Aquaculture, 301, 368-373. https://doi.org/https://doi.org/10.1016/j.aquaculture. 2018.11.054

Jiang, S., Wu, X., Li, W., Wu, M., Luo, Y., Lu, S., \& Lin, H. (2015). Effects of dietary protein and lipid levels on growth, feed utilization, body and plasma biochemical compositions of hybrid grouper (Epinephelus lanceolatus ${ }^{\lambda} \times$ Epinephelus fuscoguttatus + ) juveniles. Aquaculture, 446, 148-155. https://doi.org/10.1016/j.aquaculture.2015.04.034

Kandathil Radhakrishnan, D., AkbarAli, I., Schmidt, B. V., John, E. M., Sivanpillai, S., \& Thazhakot Vasunambesan, S. (2020). Improvement of nutritional quality of live feed for aquaculture: An overview. Aquaculture Research, 51(1), 1-17. https://doi.org/https://doi.org/10.1111/are.14357

Kumar, S., Sahu, N. P., \& Ranjan, A. (2018). Feeding DeOiled Rice Bran (DORB) to Rohu, Labeo rohita: effect of varying dietary protein and lipid level on growth, body composition and insulin like growth factor (IGF) expression. Aquaculture, 492, 59-66. https://doi.org/10.1016/j.aquaculture.2018.04.001

Liu, H., Dong, X., Tan, B., Du, T., Zhang, S., Yang, Y., ... \& Liu, H. (2021). Effects of dietary protein and lipid levels on growth, body composition, enzymes activity, expression of IGF-1 and TOR of juvenile northern whiting, Sillago sihama. Aquaculture, 533, 736166. https://doi.org/https://doi.org/10.1016/j.aquaculture. 2020.736166

Lopes, I. G., Braos, L. B., Cruz, M. C. P., \& Vidotti, R. M. (2021). Valorization of animal waste from aquaculture through composting: Nutrient recovery and nitrogen mineralization. Aquaculture, 531, 735859. https://doi.org/https://doi.org/10.1016/j.aquaculture. 2020.735859

López, L. M., Torres, A. L., Durazo, E., Drawbridge, M., \& Bureau, D. P. (2006). Effects of lipid on growth and feed utilization of white seabass (Atractoscion nobilis) fingerlings. Aquaculture, 253(1-4), 557-563. https://doi.org/https://doi.org/10.1016/j.aquaculture. 2005.08.007

Meng, Y., Qian, K., Ma, R., Liu, X., Han, B., Wu, J., ... \& Li, C. (2019). Effects of dietary lipid levels on subadult triploid rainbow trout (Oncorhynchus mykiss): 1. Growth performance, digestive ability, health status and expression of growth-related genes. Aquaculture, 513, 734394. https://doi.org/https://doi.org/10.1016/j.aquaculture. 2019.734394
Mir, I. N., Srivastava, P. P., Bhat, I. A., Jaffar, Y. D., Sushila, N., Sardar, P., ... \& Jain, K. K. (2020). Optimal dietary lipid and protein level for growth and survival of catfish Clarias magur larvae. Aquaculture, 520 , 734678 https://doi.org/https://doi.org/10.1016/j.aquaculture. 2019.734678

Nayak, M., Saha, A., Pradhan, A., Samanta, M., Mohanty, T. K., \& Giri, S. S. (2018). Influence of dietary lipid levels on growth, nutrient utilization, tissue fatty acid composition and desaturase gene expression in silver barb (Puntius gonionotous) fingerlings. Comparative Biochemistry and Physiology Part B: Biochemistry and Molecular Biology, 226, 18-25. https://doi.org/10.1016/j.cbpb.2018.08.005

Pamungkas, W., Jusadi, D., Zairin Jr, M., Setiawati, M., Supriyono, E., \& Imron, I. (2020). Effect of dietary essential fatty acids on level of oestradiol-17 $\beta$ and vitellogenin, reproductive performance and larval quality of striped catfish (Pangasianodon hypophthalmus) in out-of-spawning season. Aquaculture Research, 51(9), 3900-3909. https://doi.org/https://doi.org/10.1111/are.14738

Panserat, S., Marandel, L., Seiliez, I., \& Skiba-Cassy, S. (2019). New Insights on Intermediary Metabolism for a Better Understanding of Nutrition in Teleosts. Annual Review of Animal Biosciences, 7, 195-220. https://doi.org/10.1146/annurev-animal-020518115250

Paulino, R. R., Fortes-Silva, R., Prieto-Guevara, M. J., Rodrigues, E. J. D., Costa, L. S., Alves, A. P. D. C., ... \& Rosa, P. V. (2020). Dietary lipid level and source affect metabolic responses in hybrid catfish (Pseudoplatystoma reticulatum $\times$ Leiarius marmoratus). Aquaculture Research, 51(4), 1567-1583. https://doi.org/https://doi.org/10.1111/are.14504

Pereira, R., Basto, A., Conde-Sieira, M., Linares, F., Villanueva, J. L. R., Sieira, G. P., ... \& Valente, L. M. (2019). Growth performance and nutrient utilisation of Senegalese sole fed vegetable oils in plant proteinrich diets from juvenile to market size. Aquaculture, 511 ,

734229 https://doi.org/https://doi.org/10.1016/j.aquaculture. 2019.734229

Silva-Brito, F., Timóteo, F., Esteves, Â., Peixoto, M. J., Ozorio, R., \& Magnoni, L. (2019). Impact of the replacement of dietary fish oil by animal fats and environmental salinity on the metabolic response of European Seabass (Dicentrarchus labrax). Comparative Biochemistry and Physiology Part B: Biochemistry and Molecular Biology, 233, 46-59. https://doi.org/https://doi.org/10.1016/j.cbpb.2019.0 4.004 
Song, X., Marandel, L., Skiba-Cassy, S., Corraze, G., Dupont-Nivet, M., Quillet, E., ... \& Panserat, S. (2018). Regulation by dietary carbohydrates of intermediary metabolism in liver and muscle of two isogenic lines of rainbow trout. Frontiers in Physiology, 9, 1579. https://doi.org/10.3389/fphys.2018.01579

Tian, J., Wu, F., Yang, C. G., Jiang, M., Liu, W., \& Wen, H. (2015). Dietary lipid levels impact lipoprotein lipase, hormone-sensitive lipase and fatty acid synthetase gene expression in three tissues of adult GIFT strain of Nile tilapia, Oreochromis niloticus. Fish Physiology and Biochemistry, 41(1), 1-18. https://doi.org/10.1007/s10695-014-0001-1

Wang, J. T., Liu, Y. J., Tian, L. X., Mai, K. S., Du, Z. Y., Wang, Y., \& Yang, H. J. (2005). Effect of dietary lipid level on growth performance, lipid deposition, hepatic lipogenesis in juvenile cobia (Rachycentron canadum). Aquaculture, 249(1-4), 439-447. https://doi.org/10.1016/j.aquaculture.2005.04.038

Wang, L., Zhang, W., Gladstone, S., Ng, W. K., Zhang, J., \& Shao, Q. (2019). Effects of isoenergetic diets with varying protein and lipid levels on the growth, feed utilization, metabolic enzymes activities, antioxidative status and serum biochemical parameters of black sea bream (Acanthopagrus schlegelii). Aquaculture, 513, 734397. https://doi.org/https://doi.org/10.1016/j.aquaculture. 2019.734397

Watanabe, T. (2002). Strategies for further development of aquatic feeds. Fisheries Science, 68(2), 242-252. https://doi.org/https://doi.org/10.1046/j.14442906.2002.00418.x
Xie, R. T., Amenyogbe, E., Chen, G., \& Huang, J. S. (2021). Effects of feed fat level on growth performance, body composition and serum biochemical indices of hybrid grouper (Epinephelus fuscoguttatus $\times$ Epinephelus polyphekadion). Aquaculture, 530, 735813. https://doi.org/https://doi.org/10.1016/j.aquaculture.202 0.735813

Xu, H., Ai, Q., Mai, K., Xu, W., Wang, J., Ma, H., ... \& Liufu, Z. (2010). Effects of dietary arachidonic acid on growth performance, survival, immune response and tissue fatty acid composition of juvenile Japanese seabass, Lateolabrax japonicus. Aquaculture, 307(1-2), 75-82. https://doi.org/https://doi.org/10.1016/j.aquaculture.201 0.07 .001

Xu, H., Han, T., Li, X., Wang, J., Zheng, P., Yin, F., \& Wang, C. (2020). Effects of dietary lipid levels on survival, growth performance and antioxidant ability of the early juvenile Scylla paramamosain. Aquaculture, 528, 735559. https://doi.org/https://doi.org/10.1016/j.aquaculture. 2020.735559

Yan, J., Liao, K., Wang, T., Mai, K., Xu, W., \& Ai, Q. (2015). Dietary lipid levels influence lipid deposition in the liver of large yellow croaker (Larimichthys crocea) by regulating lipoprotein receptors, fatty acid uptake and triacylglycerol synthesis and catabolism at the transcriptional level. PloS One, 10(6), e0129937. https://doi.org/10.1371/journal.pone.0129937

Yuan, X., Liang, X. F., Liu, L., Fang, J., Li, J., Li, A., ... \& Wang, Q. (2016). Fat deposition pattern and mechanism in response to dietary lipid levels in grass carp, Ctenopharyngodon idellus. Fish physiology and biochemistry, 42(6), 1557-1569. https://doi.org/10.1007/s10695-016-0240-4 